\title{
EFFECTS OF INORGANIC FERTILIZERS AND RHIZOBIAL INOCULATION ON GROWTH, NODULATION AND TANNIN CONTENT OF ACACIELLA ANGUSTISSIMA (MILL.) BRITTON \& ROSE
}

\author{
EFECTO DE LOS FERTILIZANTES INORGÁNICOS Y LA INOCULACIÓN \\ RIZOBIAL SOBRE CRECIMIENTO, NODULACIÓN Y CONTENIDO DE \\ TANINOS EN ACACIELLA ANGUSTISSIMA (MILL.) BRITTON \& ROSE
}

\author{
Víctor M. Ruiz-Valdiviezo ${ }^{1}$, Teresa R. Ayora-Talavera ${ }^{1}$, Federico A. Gutiérrez-Miceli ${ }^{1}$, \\ Luc Dendooven ${ }^{2} \&$ Reiner Rincón-Rosales ${ }^{1}$
}

\begin{abstract}
${ }^{1}$ Departamento de Biotecnología Vegetal, Instituto Tecnológico de Tuxtla Gutiérrez, Tuxtla Gutiérrez, Carretera Panamericana km 1080, C.P. 29050, Chiapas, México; ${ }^{2}$ Laboratory of Soil Ecology, Department of Biotechnology and Bioengineering, Cinvestav, Av. I.P.N. 2508, C.P. 07360 México DF, México.

dendoove@cinvestav.mx
\end{abstract}

\section{ABSTRACT}

The effects of different inorganic fertilizers and rhizobial inoculation on shoot height, total shoot and root dry weight, nodule number, total shoot nitrogen, nitrogenase activity and tannic acid content of Acaciella angustissima (Mill.) Britton \& Rose were investigated in the laboratory. Seedlings were grown in a climate chamber in glass tubes containing sterilized mixture of vermiculite and peat moss, and treated with combinations of nitrogen $(\mathrm{N})$ at $45 \mathrm{mg}$ plant $^{-1}$, phosphorus (P) at $30 \mathrm{mg} \mathrm{plant}^{-1}$, potassium (K) at $20 \mathrm{mg} \mathrm{plant}^{-1}$ and inoculated with the bacterium Sinorhizobium mexicanum. The combined applications of $\mathrm{N}, \mathrm{P}$ or $\mathrm{K}$ to uninoculated plants increased shoot height and dry weight as compared to the unamended plantlets. The tannin content in uninoculated plants was highest when amended with $\mathrm{P}+\mathrm{K}$. Treatment had a significant effect on plant growth, nodulation and tannin content varied. The plants treated with $\mathrm{P}+$ $\mathrm{K}+S$. mexicanum had significantly longer shoot height, total shoot and root dry weight, nodule number, total shoot nitrogen, nitrogenase activity and tannic acid content in comparison with unamended plants. It was found that $\mathrm{N}$ reduced number of nodules, tannin content and nitrogenase activity of A. angustisisma. As such, farmers should refrain from applying $\mathrm{N}$ fertilizer, but could apply $\mathrm{P}$ and $\mathrm{K}$ to maximize tannin production in A. angustissima.

KeYwords: Acetylene reduction, growth chamber, N P K fertilizer, Sinorhizobium mexicanum.

\section{RESUMEN}

Se investigaron en el laboratorio los efectos de diferentes fertilizantes inorgánicos y la inoculación rizobial sobre la altura de planta, peso seco total de planta, peso seco de raíz, el número de nódulos, el nitrógeno total de la planta, la actividad de la nitrogenasa y el contenido de ácido tánico de Acaciella angustissima (Mill.) Britton \& Rose. Las plántulas fueron crecidas en una cámara climática en tubos de vidrio conteniendo una mezcla de vermiculita y turba, y tratadas con las combinaciones de nitrógeno $(\mathrm{N})$ en $45 \mathrm{mg}$ planta $^{-1}$, fósforo (P) en $30 \mathrm{mg}$ planta $^{-1}$, potasio (K) en $20 \mathrm{mg}$ planta $^{-1}$ e inoculado con la bacteria Sinorhizobium mexicanum. La combinación de las aplicaciones de N, P o K en plantas sin inocular incrementa la altura y el peso seco de planta en comparación con las plantas sin tratamiento. El contenido de taninos en plantas no inoculadas fue el más alto cuando suplementamos con $\mathrm{P}+\mathrm{K}$. El tratamiento tuvo un efecto significativo sobre el crecimiento de planta, modulación y el contenido de tanino variado. Las plantas tratadas con $\mathrm{P}+\mathrm{K}+\mathrm{S}$. mexicanum tuvieron significativamente mayor altura de planta, peso seco total de planta, peso seco de raíz, el número de nódulos, nitrógeno total de planta, actividad de la nitrogenasa y contenido de taninos en comparación con las plantas sin 
suplementar. Fue encontrado que el $\mathrm{N}$ reduce el número de nódulos, el contenido de taninos y la actividad de la nitrogenasa de $A$. angustisisma. Como tal, los agricultores deberían abstenerse de aplicar el fertilizante de $\mathrm{N}$, pero podrían aplicar P y K para maximizar la producción de tanino en A. angustissima.

Palabras ClaVe: Reducción de acetileno, cámara de crecimiento, fertilizante N P K, Sinorhizobium mexicanum.

\section{INTRODUCTION}

Acaciella angustissima (Mill.) Britton \& Rose (Fabaceae) is a shrub that was classified as a Mimosa species and later as an Acacia (RicoArce \& Rodríguez 1998). Now, it has been reclassified as Acaciella together with other American acacias (Rico-Arce \& Bachean 2006). This species has a broad geographical distribution ranging from the Southern United States to Costa Rica, and in Mexico it can be found along the Pacific coast (Dzowela 1994). In Chiapas, $A$. angustissima shrubs are often used in agroforestry systems as they grow fast and have a high capacity to fix $\mathrm{N}_{2}$ because of their symbiotic relationship between roots and nitrogen fixing bacteria (Lloret et al. 2007; Rincón-Rosales et al. 2008). Interestingly, these shrubs are the preferred hosts of Llaveia mexicanorum (Williams \& MacVean 1995), a native homeoptera scale insect, which is used by indigenous people of Chiapas and Mesoamerica to produce a fat for traditional lacquer wood hand crafts (Grillasca 2007). A angustissima can grow under different climatic conditions in various ecosystems and in soils with different amounts of organic material and large differences in nutrient availability (Rincón-Rosales \& Gutiérrez-Miceli 2008).

Inorganic $\mathrm{N}$ fertilizer can have an effect, being it positive or negative, on plant nodulation, $\mathrm{N}_{2}$ fixation and seedling growth of leguminous plants (Huda et al. 2007). Phosphorus has been shown to increase plant growth and stimulate nodulation in legumes (Räsänen \& Lindström 2003). Potassium stimulates transport of molecules through the membrane, enzyme activity and cell growth (Ashley et al. 2006). Nitrogen is involved in cell division and biosynthesis of molecules in plant growth (Buchanan et al. 2000). High concentration of inorganic $\mathrm{N}$ in the soil normally inhibits symbiotic nitrogen fixation (Hungria \& Vargas 2000), but not always (Davidson \& Robson
1986) and changes the synthesis of phenolic compounds in legumes (Barahona et al. 1997). A. angustissima accumulates phenolitic compounds in its bark, i.e. tannins, and they are used as a defense against fungi and bacteria (O'Donovan $\&$ Brooker 2001). Plants growing in nutrient-poor soil often contain high concentrations of tannins (Northup et al. 1995, Kraus et al. 2003, Kraus et al. 2004). In woody species, the concentration of foliar tannin commonly range from 15 to $25 \%$ dry weight (Booker \& Maier 2001, Osier \& Lindroth 2001), but amounts as high as $40 \%$ have been reported (Kuiters 1990, Matthews et al. 1997). As such, tannin could be extracted for industrial purposes. Tannins are traditionally used to tan hide. A. angustissima could be cultivated in marginalized land providing the farmers with an additional income while restoring soil fertility and preventing soil erosion. Fertilizing A. angustissima might thus affect tannin content in its bark. As part of a project to reforestate and restore soil fertility in large parts of central Chiapas, the effect of $\mathrm{N}$, P, K and Sinorhizobium mexicanum (Lloret et al. 2007) on growth, tannin and $\mathrm{N}$ content, nodulation and a nitrogenase activity of $A$. angustissima was studied in the laboratory.

\section{MATERIALS AND METHODS}

SEED COLLECTION, PRETREATMENT AND GERMINATION Mature pods were collected from $A$. angustissima shrubs growing in the Sumidero Canyon National Park in Chiapas, Mexico (16 48' N; 93 $93^{\circ} 04^{\prime} \mathrm{W}$ ). The site is 900 to $1600 \mathrm{~m}$ above sea level on a gently sloping hill westerly orientated. The pods were sun-dried three days and the seeds extracted. Healthy seeds of uniform weight were scarified with $\mathrm{H}_{2} \mathrm{SO}_{4}$ for 10 min and surface sterilized with $1 \%(\mathrm{v} / \mathrm{v})$ hypochlorite for $10 \mathrm{~min}$ (Rincón-Rosales et al. 2003). Treated seeds were germinated on 0.8 $\%$ agar-water plates at $28{ }^{\circ} \mathrm{C}$ in the dark for $48 \mathrm{~h}$ (Rincón-Rosales et al. 2008). 


\section{BACTERIAL STRAIN}

The $S$. mexicanum strain ITTG $\mathrm{R}^{\mathrm{T}}$ was provided by the ITTG bacterial culture collection (Tecnológico de Tuxtla Gutierrez, Chiapas, México). This strain was isolated from $A$. angustissima root nodules in Chiapas and is a fast-growing rhizobia (Lloret et al. 2007). The strain was grown on yeast extract manitol agar (YEM) and peptone yeast (PY) media at $28{ }^{\circ} \mathrm{C}$ and preserved at $4{ }^{\circ} \mathrm{C}$ until used (Toledo et al. 2003).

Plant MATERIAL AND GROWTH CONDITIONS

A. angustissima seeds were scarified with $\mathrm{H}_{2} \mathrm{SO}_{4}$ for $15 \mathrm{~min}$ and the surface sterilized with $1 \%(\mathrm{v} /$ v) sodium hypochlorite for $10 \mathrm{~min}$. Treated seeds were germinated on $0.8 \%$ agar-water plates and incubated in the dark at $25^{\circ} \mathrm{C}$ for $48 \mathrm{~h}$ to induce etiolation (Rincón-Rosales et al. 2003). The seedlings with a root of approximately $2 \mathrm{~cm}$ were placed in glass tubes $(\varnothing 2 \mathrm{~cm}$ and length $20 \mathrm{~cm}$ ), i.e. two seeds per tube, containing a mixture of sterilized vermiculite ${ }^{\mathrm{TM}}$-peat $\operatorname{moss}^{\mathrm{TM}}$ (1:1) and moistened with a NPK-free Fahraeus solution (Fahraeus 1957). The tubes were closed first with a rubber-foam stopper and then with aluminium foil.

\section{TREATMENTS AND EXPERIMENTAL DESIGN}

Sixteen different treatments were applied and four plants were used per treatment combining application of phosphorus $(\mathrm{P})$, nitrogen $(\mathrm{N})$, potassium $(\mathrm{K})$ and inoculation with $S$. mexicanum (B) (Table I). Nitrogen was applied at $45 \mathrm{mg}$ $\left(\mathrm{NH}_{4}\right)_{2} \mathrm{NO}_{3}-\mathrm{N}$ per tube, $\mathrm{P}$ at $30 \mathrm{mg} \mathrm{NaH} \mathrm{PO}_{4}-\mathrm{P}$ and $\mathrm{K}$ at $45 \mathrm{mg} \mathrm{K} \mathrm{SO}_{4}-\mathrm{K}$ at transplanting. The plants arranged completely at random were grown in a climate chamber at $28^{\circ} \mathrm{C}$ with a $14 \mathrm{~h}$ light/ $10 \mathrm{~h}$ dark photoperiod (Räsänen \& Lindström 2003). Lighting was provided by fluorescent lamps with $50 \mu \mathrm{mol} \mathrm{m} \mathrm{m}^{-2} \mathrm{~s}^{-1}$ light intensity. After 5 days, half of the plantlet roots were inoculated with $1 \mathrm{ml}$ medium containing $10^{6} \mathrm{~S}$. mexicanum ITTG R7 $7^{\mathrm{T}}$ cells. Each fifteen days, all plants were irrigated with sterile 5 ml NPK-free Fahraeus solution.

\section{Plant Characteristics}

After 90 days of cultivation, plants were taken from the glass tubes, the substrate was washed from the roots and shoot height, total dry weight and root dry weight was determined. Roots and shoots were oven-dried at $60^{\circ} \mathrm{C}$ for $48 \mathrm{~h}$ until a constant weight was obtained. The dry roots and shoots were hammer milled and an $80 \mathrm{mg}$ sub-sample of the shoot was analyzed for total $\mathrm{N}$ by microKjeldahl (Bremmer 1996).

The effective nodules, i.e. red or brown coloured, were separated from the roots, cleaned, counted and weighed (Vincent 1970). Nitrogenase activity in the nodules ( $\mathrm{N}_{2}$ fixation) was measured by the acetylene reduction assay (ARA) (Hardy 1968). The nodules were placed in a $25 \mathrm{ml}$ vial, $600 \mu \mathrm{l}$ air was removed and replaced with acetylene $\left(\mathrm{C}_{2} \mathrm{H}_{2}\right)$ and incubated at $30^{\circ} \mathrm{C}$. After $2 \mathrm{~h}$, the headspace of the vial was sampled and analyzed for ethylene production using a Varian model 3300 GC fitted with a flame ionization detector (FID) fitted with a porapak $\mathrm{N}$ column $(300 \times 0.1 \mathrm{~cm})$. $\mathrm{N}_{2}$ fixation was expressed as micromoles of ethylene produced per nodule per $\mathrm{h}$.

A $30 \mathrm{mg}$ sub-sample of each root and shoot was analyzed for tannin content using the tungstenmolybdenum-phosphorus method (Miranda 2000).

\section{Statistical ANALYSIS}

Significant difference among plant characteristics as a result of the different treatments were determined by analysis of variance (ANOVA) and based on the least significant difference using the General Linear Model procedure PROC GLM (SAS Institute 1989). This procedure can be used for an analysis of variance (ANOVA) for unbalanced data, i.e. when some data are missing. Correlation coefficients were calculated with PROC CORR (SAS Institute 1989).

The relationships between the different plant characteristics, i.e. total plant $\mathrm{N}$ and tannin content, shoot height, root and above ground plant dry weight, number of nodules and nitrogenase activity, for plants not inoculated were analyzed by principal component analysis (PCA) using the orthogonal/ varimax rotation to achieve either small or large component loading and an eigenvalue of 1 as the lower limit. For those plants inoculated with $S$. mexicanum the number of nodules and nitrogenase activity were additionally included in the PCA analysis. Variables were auto-scaled prior to PCA (Sena et al. 2002). The number of components was determined by the Eigenvalue-one criterion (Kaiser 1960). Moreover, a scree test (Catell 1966) was performed to corroborate primer results, only principal components with Eigenvalues $>1$ and/or that explained $>10 \%$ of the total variance were 
Inorganic fertilizers and rhizobial inoculation of Acaciella angustissima: RuIz-VALDIVIEZo, V.M. ET AL.

retained. A VARIMAX rotation was performed to enhance interpretability of the uncorrelated components (Flury \& Riedwyl 1988). A PCA often reveals previously unsuspected associations among variables and thereby allows interpretation that would not be possible otherwise (Johnson \& Wichern 1998). The matrix of 16 columns (treatments) and 7 (not inoculated) or 9 (inoculated with $S$. mexicanum) lines (variables) was used for principal component analysis. All analyses were performed using the SAS statistical package (SAS Institute 1989). All data presented were the mean of four plants cultivated $(n=4)$.

\section{RESULTS}

Shoot height varied between $13.3 \mathrm{~cm}$ when only $\mathrm{N}$ and $21.1 \mathrm{~cm}$ when $\mathrm{N}+\mathrm{P}+\mathrm{K}$ was added (Table I). $\mathrm{P}$ had a positive highly significant effect on shoot height $(\mathrm{P}<0.0001)$ (Table II). Plant weight was the lowest when only $\mathrm{P}$ was added to the plants and the highest when inoculated with $S$. mexicanum and amended with $\mathrm{P}+\mathrm{K}$ (Table I). P, K, S. mexicanum $+\mathrm{N}, S$. mexicanum $+\mathrm{P}$ and $\mathrm{N}+\mathrm{K}$ had a significant positive effect on plant weight (Table II). Root weight and total plant $\mathrm{N}$ content were lowest in the untreated plants and highest when inoculated

TABLE I. Effect of the treatment on height of A. angustissima, plant and root dry weight, total plant $\mathrm{N}$ and tannin content and number of nodules.

TABLA I. Efecto de los tratamientos sobre la altura de A. angustissima, el peso seco de planta y el peso seco raíz, el N total de planta y el contenido de taninos y el número de nódulos.

\begin{tabular}{|c|c|c|c|c|c|c|c|}
\hline & $\begin{array}{l}\text { Shoot } \\
\text { height } \\
(\mathrm{cm})\end{array}$ & \multicolumn{2}{|c|}{ (mg) } & \multicolumn{2}{|c|}{$\left(\mathrm{mg} \mathrm{kg}^{-1}\right)$} & Nodules & $\begin{array}{l}\mathrm{N}_{2} \text { fixing capacity } \\
\left(\mu \mathrm{mol} \mathrm{C}_{2} \mathrm{H}_{4} \text { nodule }\right. \\
\left.\text { fresh weight }{ }^{-1} \mathrm{~h}^{-1}\right)\end{array}$ \\
\hline Untreated & $13.6 \mathrm{~b}$ & $23 \mathrm{~b}$ & $4 \mathrm{~b}$ & $0.3 \mathrm{~d}$ & 9.8 defg & 0 & 0 \\
\hline $\begin{array}{l}\text { Nitrogen (N) (45 mg N } \\
\left.\text { plant }^{-1}\right)\end{array}$ & $13.3 \mathrm{~b}$ & $32 \mathrm{~b}$ & $8 a b$ & $1.2 \mathrm{abc}$ & $10.8 \mathrm{~d}$ & 0 & 0 \\
\hline $\begin{array}{l}\text { Phosphorus (P) (30 mg N } \\
\left.\text { plant }^{-1}\right)\end{array}$ & $15.3 \mathrm{ab}$ & $22 \mathrm{~b}$ & $7 \mathrm{~b}$ & $0.8 \mathrm{bcd}$ & $10.4 \mathrm{de}$ & 0 & 0 \\
\hline $\begin{array}{l}\text { Potassium (K) (20 mg N } \\
\left.\text { plant }^{-1}\right)\end{array}$ & $14.8 \mathrm{ab}$ & $29 \mathrm{~b}$ & $9 a b$ & $0.7 \mathrm{~cd}$ & $9.1 \mathrm{~g}$ & 0 & 0 \\
\hline $\mathrm{N}+\mathrm{P}$ & $15.6 \mathrm{ab}$ & $48 \mathrm{ab}$ & $15 \mathrm{ab}$ & $0.7 \mathrm{~cd}$ & $9.4 \mathrm{fg}$ & 0 & 0 \\
\hline $\mathrm{N}+\mathrm{K}$ & $13.3 \mathrm{~b}$ & $40 \mathrm{ab}$ & $12 \mathrm{ab}$ & $0.4 \mathrm{~d}$ & 9.9 defg & 0 & 0 \\
\hline $\mathrm{P}+\mathrm{K}$ & $16.0 \mathrm{ab}$ & $33 \mathrm{~b}$ & $13 \mathrm{ab}$ & $0.8 \mathrm{bcd}$ & $14.5 \mathrm{c}$ & 0 & 0 \\
\hline $\mathrm{N}+\mathrm{P}+\mathrm{K}$ & $21.1 \mathrm{a}$ & $44 \mathrm{ab}$ & $11 \mathrm{ab}$ & $1.4 \mathrm{ab}$ & $10.5 \mathrm{~d}$ & 0 & 0 \\
\hline S. mexicanum (B) & $15.1 \mathrm{ab}$ & $20 \mathrm{~b}$ & $11 \mathrm{ab}$ & $1.1 \mathrm{abcd}$ & $14.9 \mathrm{c}$ & 3 ed & $308 \mathrm{c}$ \\
\hline $\mathrm{B}+\mathrm{N}$ & $13.6 \mathrm{~b}$ & $26 \mathrm{~b}$ & $6 \mathrm{~b}$ & $0.5 \mathrm{~cd}$ & 9.6 efg & $1 \mathrm{e}$ & $32 \mathrm{~h}$ \\
\hline $\mathrm{B}+\mathrm{P}$ & $16.9 \mathrm{ab}$ & $28 \mathrm{~b}$ & $10 \mathrm{ab}$ & $0.5 \mathrm{~cd}$ & $16.0 \mathrm{~b}$ & $3 \mathrm{c}$ & $320 \mathrm{c}$ \\
\hline $\mathrm{B}+\mathrm{K}$ & $16.4 \mathrm{ab}$ & $36 \mathrm{~b}$ & $9 \mathrm{ab}$ & $0.8 \mathrm{~cd}$ & $16.1 \mathrm{~b}$ & $4 \mathrm{~b}$ & $401 \mathrm{~b}$ \\
\hline $\mathrm{B}+\mathrm{N}+\mathrm{P}$ & $16.5 \mathrm{ab}$ & $50 \mathrm{ab}$ & $10 a b$ & $0.9 \mathrm{abcd}$ & $10.4 \mathrm{de}$ & $1 \mathrm{e}$ & $67 \mathrm{~g}$ \\
\hline $\mathrm{B}+\mathrm{N}+\mathrm{K}$ & $15.0 \mathrm{ab}$ & $23 \mathrm{~b}$ & $10 a b$ & $0.6 \mathrm{~cd}$ & $10.7 \mathrm{~d}$ & $1 \mathrm{e}$ & $257 \mathrm{~d}$ \\
\hline $\mathrm{B}+\mathrm{P}+\mathrm{K}$ & $18.4 \mathrm{ab}$ & $70 \mathrm{a}$ & $21 \mathrm{a}$ & $1.6 \mathrm{a}$ & $21.4 \mathrm{a}$ & $7 \mathrm{a}$ & $600 \mathrm{a}$ \\
\hline $\mathrm{B}+\mathrm{N}+\mathrm{P}+\mathrm{K}$ & $20.1 \mathrm{ab}$ & $46 \mathrm{ab}$ & $12 \mathrm{ab}$ & $1.0 \mathrm{abcd}$ & $10.3 \mathrm{def}$ & $2 \mathrm{dc}$ & $99 \mathrm{f}$ \\
\hline $\operatorname{MSD}(\mathrm{P}<0.05)$ & 4.0 & 21 & 8 & 0.7 & 0.8 & 0.7 & 15 \\
\hline
\end{tabular}


Gayana Bot. 66(2), 2009

TABLE II. P-value for the effect of $S$. mexicanum, nitrogen, phosphorus, potassium and the interactions among them on height of $A$. angustissima, plant and root dry weight, total plant $\mathrm{N}$ and tannin content and number of nodules.

TABLA II. Valores de P para el efecto de Sinorhizobium mexicanum, nitrógeno, fósforo, potasio y las interacciones entre ellos sobre la altura de $A$. angustissima, el peso seco de planta y el peso seco raíz, el $\mathrm{N}$ total de planta y el contenido de taninos y el número de nódulos.

\begin{tabular}{|c|c|c|c|c|c|c|c|}
\hline & $\begin{array}{l}\text { Shoot } \\
\text { height } \\
(\mathrm{cm})\end{array}$ & Plant weight & Root weight & N-plant & Tannin & Nodules & $\begin{array}{c}\mathrm{N}_{2} \text { fixing } \\
\text { capacity } \\
\left(\mu \text { mol } \mathrm{C}_{2} \mathrm{H}_{4}\right. \\
\text { nodule fresh } \\
\left.\text { weight }^{-1} \mathrm{~h}^{-1}\right)\end{array}$ \\
\hline $\begin{array}{l}\text { Sinorhizobium } \\
\text { mexicanum (B) }\end{array}$ & 0.1196 & 0.3275 & 0.3279 & 0.4801 & $<0.0001$ & $<0.0001$ & $<0.0001$ \\
\hline Nitrogen $(\mathrm{N})$ & 0.7263 & 0.1034 & 0.9130 & 0.9791 & $<0.0001$ & $<0.0001$ & 0.5795 \\
\hline Phosphorus (P) & $<0.0001$ & 0.0003 & 0.133 & 0.0231 & $<0.0001$ & $<0.0001$ & 0.0006 \\
\hline Potassium (K) & 0.0106 & 0.0179 & 0.0282 & 0.1851 & $<0.0001$ & $<0.0001$ & 0.2431 \\
\hline$B * N$ & 0.3465 & 0.0282 & 0.0206 & 0.0426 & $<0.0001$ & $<0.0001$ & 0.5795 \\
\hline $\mathrm{B} * \mathrm{P}$ & 0.8199 & 0.0271 & 0.6783 & 0.8957 & 0.1442 & $<0.0001$ & 0.0006 \\
\hline $\mathrm{B}^{*} \mathrm{~K}$ & 0.9581 & 0.3193 & 0.8441 & 0.3887 & 0.0010 & $<0.0001$ & 0.2431 \\
\hline $\mathrm{N}^{*} \mathrm{P}$ & 0.0485 & 0.5000 & 0.7105 & 0.7731 & 0.0005 & 0.0044 & 0.1302 \\
\hline $\mathrm{N} * \mathrm{~K}$ & 0.3291 & 0.0089 & 0.2682 & 0.3608 & $<0.0001$ & 0.0011 & 0.0390 \\
\hline $\mathrm{P} * \mathrm{~K}$ & 0.1872 & 0.5671 & 0.6467 & 0.0092 & $<0.0001$ & 0.0363 & 0.8520 \\
\hline $\mathrm{B} * \mathrm{~N} * \mathrm{P}$ & 0.5877 & 0.7004 & 0.8784 & 0.5824 & 0.6030 & 0.0074 & 0.1302 \\
\hline $\mathrm{B} * \mathrm{~N}^{*} \mathrm{~K}$ & 0.8064 & 0.0785 & 0.5559 & 0.8957 & 0.0434 & $<0.0001$ & 0.0390 \\
\hline $\mathrm{N} * \mathrm{P} * \mathrm{~K}$ & 0.1707 & 0.1302 & 0.0466 & 0.5821 & $<0.0001$ & 0.5925 & 0.3264 \\
\hline $\mathrm{B} * \mathrm{~N} * \mathrm{P} * \mathrm{~K}$ & 0.6959 & 0.5307 & 0.3190 & 0.0042 & 0.0009 & 0.1441 & 0.6042 \\
\hline
\end{tabular}

with $S$. mexicanum and amended with $\mathrm{P}+\mathrm{K}$ (Table I). $\mathrm{P}$ and the interactions between $S$. mexicanum and $\mathrm{N}$ and $\mathrm{N}+\mathrm{P}+\mathrm{K}$ had a significant effect on root weight (Table II). P and the interactions between $\mathrm{P}$ and $\mathrm{K}$ and $\mathrm{S}$. mexicanum and $\mathrm{N}+\mathrm{P}+\mathrm{K}$ had a significant effect on total plant N (Table II). Tannin content of the plants was lowest when only $\mathrm{P}$ was added to the plants and highest when inoculated with $S$. mexicanum and amended with $\mathrm{P}+\mathrm{K}$ (Table 1). All factors $(\mathrm{P}<0.0001)$ and interactions between them $(\mathrm{P}<0.05)$ had a significant effect on the plant tannin content, except for the interactions between $S$. mexicanum and $\mathrm{P}$, and $S$. mexicanum and $\mathrm{N}+\mathrm{P}$ (Table II). Seven nodules were found when plants were inoculated with $S$. mexicanum and amended with $\mathrm{P}+\mathrm{K}$, but only one when amended with $\mathrm{N}$, $\mathrm{N}+\mathrm{P}$ or $\mathrm{N}+\mathrm{K}$ (Table I). All factors $(\mathrm{P}<0.0001)$ and interactions between them $(\mathrm{P}<0.05)$ had a significant effect on the nodule number, except for the $\mathrm{N}+\mathrm{P}+\mathrm{K}$ combination and the interaction between $S$. mexicanum and $\mathrm{N}+\mathrm{P}+\mathrm{K}$ (Table II). The lowest $\mathrm{N}_{2}$ fixing capacity was found when plants were inoculated with $S$. mexicanum and amended with $\mathrm{N}$, and the highest when amended with $\mathrm{P}+\mathrm{K}$ (Table I). All factors $(\mathrm{P}<0.0001)$ and interactions between them $(\mathrm{P}<0.05)$ had a significant effect on the $\mathrm{N}_{2}$ fixing capacity of the plants, except for the interactions between $S$. mexicanum and $\mathrm{N}, S$. mexicanum and $\mathrm{K}, S$. mexicanum and $\mathrm{N}+$ $\mathrm{P}, \mathrm{S}$. mexicanum and $\mathrm{N}+\mathrm{K}$ and $S$. mexicanum and $\mathrm{N}+\mathrm{P}+\mathrm{K}$ (Table II).

\section{PRINCIPAL COMPONENT ANALYSIS}

Loading for parameters obtained after VARIMAX rotation are given in Table III. A first PC (PC1), only considering the plants not inoculated with $S$. mexicanum, explained $37 \%$ of variation, a second $24 \%$ and a third $21 \%$. PC1 had a positive loading from root and plant weight, $\mathrm{PC} 2$ from shoot height and total plant $\mathrm{N}$ content and $\mathrm{PC} 3$ from tannin and total $\mathrm{N}$ content. On the scatter plot with $\mathrm{PC} 1$ and $\mathrm{PC} 2$, the treatments are visually distinct (Fig. 
Inorganic fertilizers and rhizobial inoculation of Acaciella angustissima: RuIZ-VALDIVIEzo, V.M. ET AL.

1a). The unamended plants or those amended only with $\mathrm{N}, \mathrm{P}$ or $\mathrm{K}$ were the lightest, i.e. a negative PC1 value, while combination of the aforementioned nutrients resulted in heavier plants. The tallest plants and those with the highest $\mathrm{N}$ content, i.e. highest $\mathrm{PC} 2$, were found when plants were amended with the three nutrients. Plants with the largest tannin content, i.e. a high positive PC3, were obtained when fertilized with $\mathrm{P}+\mathrm{K}$ (Fig. 1b).
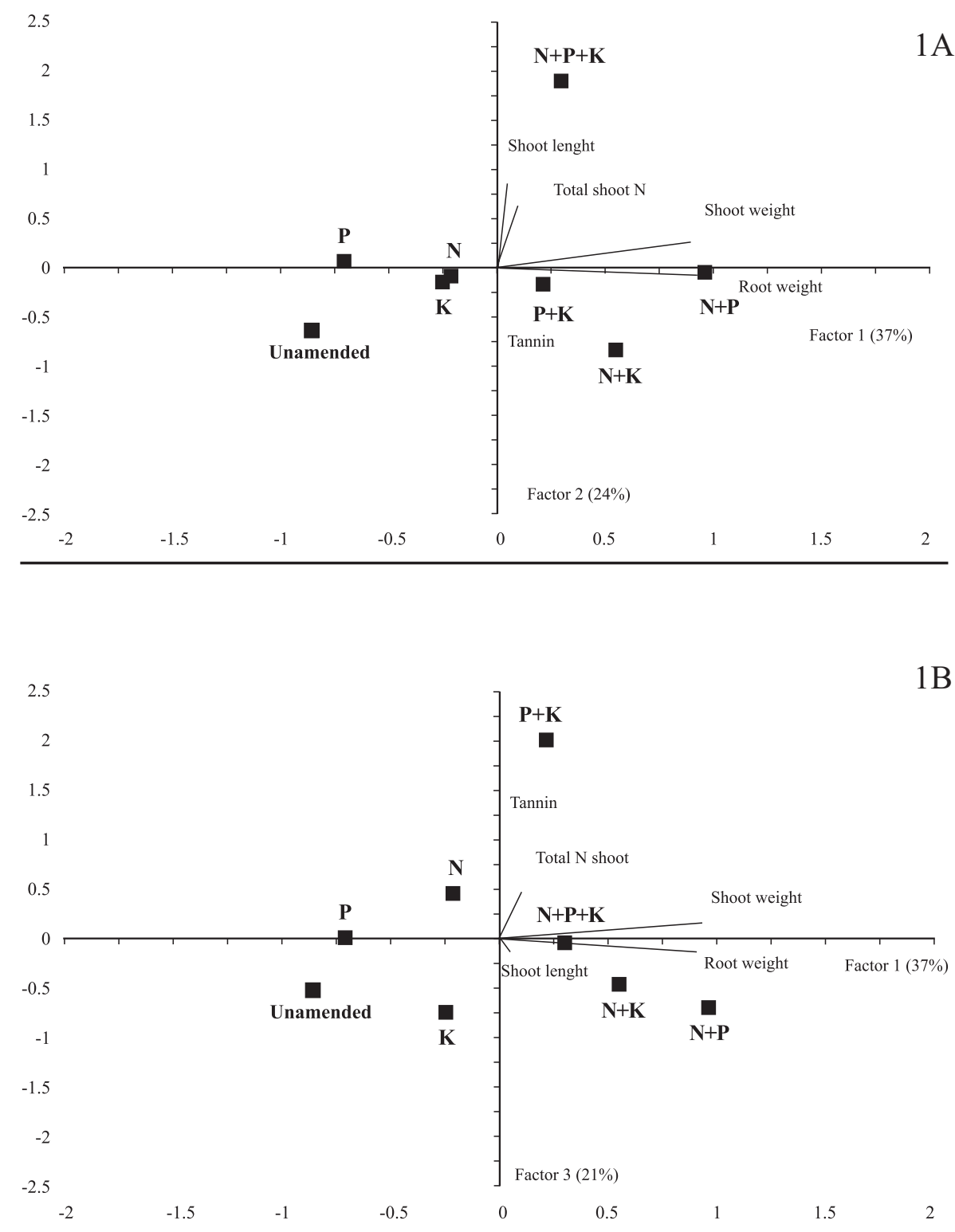

FIGURE 1. Principal component analysis (PCA) performed on characteristics, i.e. shoot height, shoot and root weight, total $\mathrm{N}$ and tannin content of uninoculated A. angustissima. With A) depicting factor 1 and factor 2, while $\mathrm{B}$ ) draws factor 1 and factor 3.

Figura 1. Análisis de componentes principales (PCA) realizado sobre la altura de planta, peso de planta, peso de raíz, $\mathrm{N}$ total y el contenido de tanino de A. angustissima no inoculada. Con A) representado el factor 1 y factor 2 , mientras B) muestra el factor 1 y factor 3 . 
Gayana Bot. 66(2), 2009

A first PC, only considering the plants inoculated with $S$. mexicanum, explained $54 \%$ of variation, a second $19 \%$ and a third $14 \%$ (Table III). PC1 had a positive loading from $\mathrm{N}$ and tannin content, nitrogenase activity and number of nodules, PC2 from plant and root weight, and PC3 from root and plant weight and shoot height. On the scatter plot with PC1 and PC2, the treatments are visually distinct (Fig. 2a). Fertilizing the plants with $\mathrm{N}$ reduced the number of nodules, nitrogenase activity and tannin content, compared to plants not amended with N. Adding P or K increased number of nodules, nitrogenase activity and tannin content, and combining both nutrients further increased these characteristics. Shoot height and weight was larger when all nutrients or $\mathrm{N}+\mathrm{P}$ or $\mathrm{P}+\mathrm{K}$ were added to the inoculated plants, i.e. positive PC2, compared to the other treatments. The plants with highest biomass were found when $\mathrm{P}+\mathrm{K}$ was added to the inoculated plants (Fig. 2b).

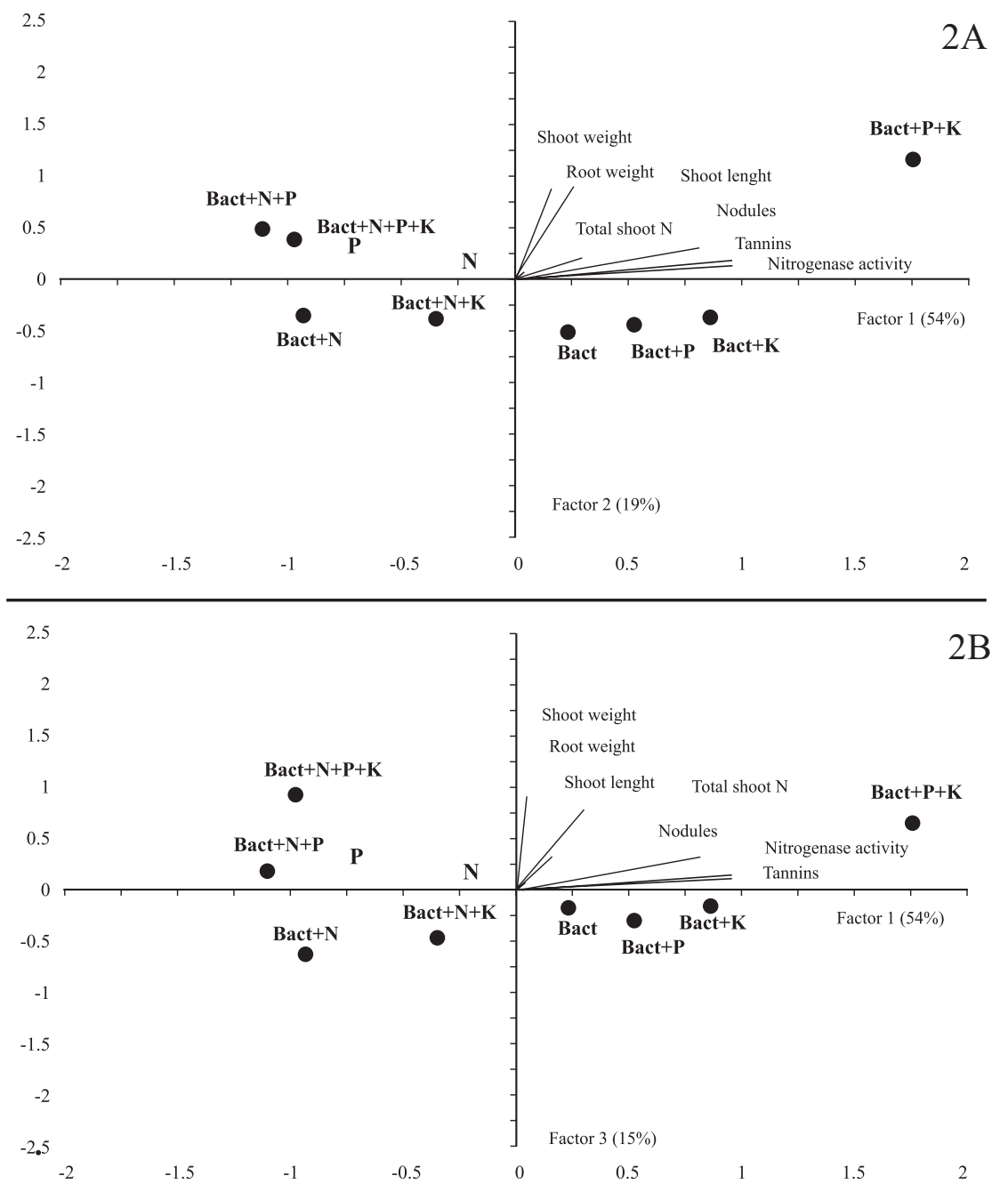

FIGURE 2. Principal component analysis (PCA) performed on characteristics, i.e. shoot height, shoot and root weight, total $\mathrm{N}$ and tannin content, number of nodules and $\mathrm{N}_{2}$ fixing capacity, of $A$. angustissima inoculated with Sinorhizobium mexicanum after a varimax rotation. With A) depicting factor 1 and factor 2, while B) draws factor 1 and factor 3 .

FIGURA 2. Análisis de componentes principales (PCA) realizado sobre la altura de planta, peso de planta, peso de raíz, $\mathrm{N}$ total, el contenido de tanino, número de nódulos y la capacidad de fijación de $\mathrm{N}$ de A. angustissima inoculada con Sinorhizobium mexicanum después de una rotación varimax. Con A) representado el factor 1 y factor 2, mientras B) muestra el factor $1 \mathrm{y}$ factor 3. 
Inorganic fertilizers and rhizobial inoculation of Acaciella angustissima: RuIZ-VALDIVIEzo, V.M. ET AL.

A first PC, considering all treatments, explained $54 \%$ of variation, a second $19 \%$ and a third 15\% (Table III). PC1 had positive loading from root and plant weight, PC2 from shoot height and total plant $\mathrm{N}$ content and PC3 from plant tannin content. The unamended plants were the lightest, i.e. a negative PC1 value, inoculating plants with $S$. mexicanum and adding $\mathrm{P}+\mathrm{K}$ as nutrients resulted in the heaviest plants (Fig. 3a). The tallest plants and those with the highest $\mathrm{N}$ content, i.e. highest PC2, were found when plants were amended with the three nutrients. Plants with the largest tannin content, i.e. a high positive PC3, were obtained when inoculated and fertilized with $\mathrm{P}+\mathrm{K}$ while generally $\mathrm{N}$ fertilizer or the absence of $S$. mexicanum reduced it (Fig. 3b).

TABLE III. Rotated loadings on the principal components.

TABLA III. Carga rotacional sobre los componentes principales.

\begin{tabular}{|c|c|c|c|c|c|c|c|c|c|}
\hline & \multicolumn{3}{|c|}{ Without inoculum } & \multicolumn{3}{|c|}{ With S. mexicanum } & \multicolumn{3}{|c|}{$\begin{array}{c}\text { With and without } S \text {. } \\
\text { mexicanum }\end{array}$} \\
\hline & $\mathrm{PC} 1$ & $\mathrm{PC} 2$ & PC3 & $\mathrm{PC} 1$ & PC2 & PC3 & PC1 & PC2 & PC3 \\
\hline Eigenvalues & 1.85 & 1.21 & 1.04 & 3.8 & 1.38 & 1.03 & 2.30 & 1.08 & 0.81 \\
\hline Proportions & 37 & 24 & 21 & 52 & 29 & 15 & 46 & 22 & 16 \\
\hline \multicolumn{10}{|c|}{ Rotated loading on three retained components ${ }^{b}$} \\
\hline Shoot height & 1 & $86^{\mathrm{a}}$ & -12 & 12 & 88 & $90^{\text {a }}$ & 10 & $88^{\text {a }}$ & -5 \\
\hline Plant weight & $90^{\text {a }}$ & 27 & -13 & 26 & $88^{a}$ & 32 & $89^{\text {a }}$ & 29 & 6 \\
\hline Root weight & $93^{\mathrm{a}}$ & -9 & 16 & 26 & $91^{\text {a }}$ & 2 & $93^{\text {a }}$ & -2 & 20 \\
\hline Total $\mathrm{N}$ content & 10 & $64^{a}$ & $47^{\text {a }}$ & $30^{\mathrm{a}}$ & 21 & $78^{a}$ & 13 & $73^{a}$ & 37 \\
\hline Tannin content & 1 & -1 & $94^{\text {a }}$ & $96^{\mathrm{a}}$ & 18 & 11 & 17 & 11 & $95^{\mathrm{a}}$ \\
\hline Nodules & ND & ND & ND & $92^{a}$ & 31 & 27 & ND & ND & ND \\
\hline $\begin{array}{l}\mathrm{N}_{2} \text { fixing } \\
\text { capacity }\end{array}$ & $\mathrm{ND}$ & ND & ND & 96 & 14 & 9 & ND & ND & ND \\
\hline
\end{tabular}

a Parameters with significant loadings on the within column principal component / Parámetros con cargas significativas dentro de la columna de componentes principales.

${ }^{\mathrm{b}}$ Only principal components with Eigenvalues $>1$ and that explain $>10$ of the total variance were retained / Solamente componentes principales con valores propios $>1$ y esto explica que $>10$, de la varianza total, fueron conservados.

ND: Not determined / No determinado. 
Gayana Bot. 66(2), 2009

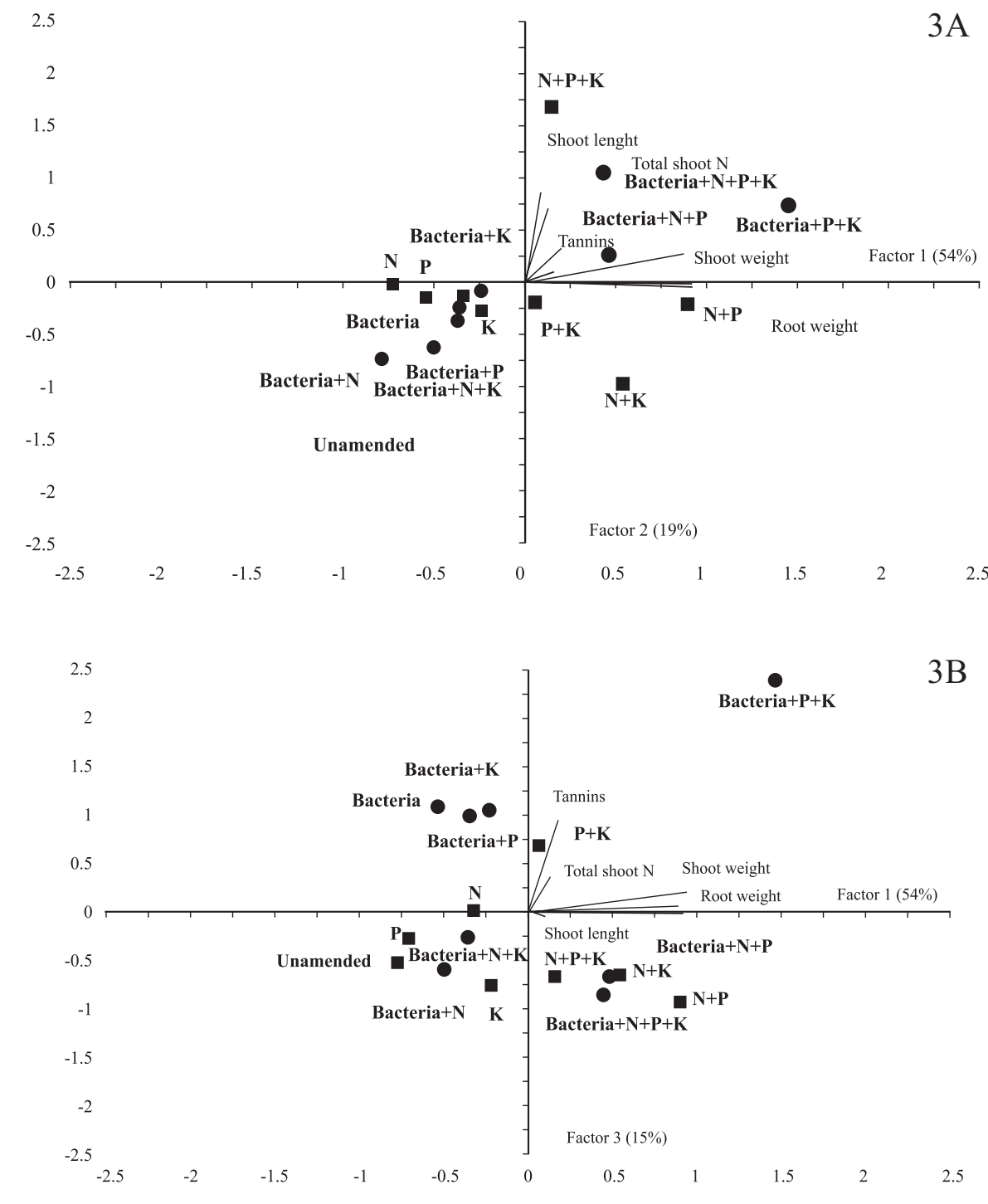

FIGURE 3. Principal component analysis (PCA) performed on characteristics, i.e. shoot height, shoot and root weight, total $\mathrm{N}$ and tannin content, number of nodules and $\mathrm{N}_{2}$ fixing capacity of $A$. angustissima inoculated or not with Sinorhizobium mexicanum after a varimax rotation. With A) depicting factor 1 and factor 2, while B) draws factor 1 and factor 3.

FIGURA 3. Análisis de componentes principales (PCA) realizado sobre la altura de planta, peso de planta, peso de raíz, $\mathrm{N}$ total, el contenido de tanino, número de nódulos y la capacidad de fijación de $\mathrm{N}$ de $A$. angustissima inoculada o no con Sinorhizobium mexicanum después de una rotación varimax. Con A) representado el factor 1 y factor 2, mientras B) muestra el factor $1 \mathrm{y}$ factor 3 . 


\section{DISCUSSION}

Nitrogen is one of the most critical nutrients for normal plant development. Leguminous plants have overcome the limitation of nitrogen by forming symbiotic relationship with $\mathrm{N}_{2}$ fixing bacteria (Räsänen \& Lindström 2003). When no symbiotic relationship can be formed, such as in $A$. angustissima plants cultivated in sterile peat moss, $\mathrm{N}$ becomes the most limiting nutrient. In the peat moss used, there was a lack of $\mathrm{P}$, but its positive effect on the development of A. angustissima was smallest. The combination of these nutrients stimulated morphological growth, biomass production, biological fixation of nitrogen and tannins content of $A$. angustissima seedlings.

Fertilizing legumes with $\mathrm{N}$ is known to inhibit nodule formation, but not always (Fujikake et al. 2003). Low concentration of inorganic N, i.e. ammonium or nitrate, have been shown to actually promote nodulation, but a larger concentration nearly always suppresses it (Davidson \& Robson 1986). Legumes use soil $\mathrm{N}$ if available, because formation of nodules requires additional energy and nutrient substances from the plant (Turk et al. 1993). Soil nitrogen concentrations (trough roots) will regulate formation of nodules (Rhoades \& Coleman 1999). Inorganic $\mathrm{N}$ added to $A$. angustissima cultivated in peat moss reduced nodule formation and nitrogenase activity.

Lack of inorganic $\mathrm{N}$ fertilizer increased tannin concentrations in $A$. angustissima. Plant tannin contents are affected by stress conditions (Kraus et al. 2004). A number of studies have examined changes in plant chemistry in response to variations in nutrients, light, moisture, ozone and $\mathrm{CO}_{2}$ (Penuelas \& Estiarte 1998, Hättenschwiler et al. 2003, Kraus et al. 2003). Most investigations found that phenolic and tannin concentrations increased when nutrient availability decreased and/or $\mathrm{C}$ availability increased. Plants growing in nutrient limited conditions often contain high concentrations of foliar tannins and other phenolics (Northup et al. 1998). This suggests that there may be a feedback wherein lack of nutrients increases secondary compound production leading to lower litter quality, which further contributes to poor soil conditions (Van Breemen \& Finzi 1998). Plant secondary compounds, such as polyphenols and tannins, affect nutrient cycling in soil by inhibiting organic matter degradation, mineralization rates and
$\mathrm{N}$ availability (Kraus et al. 2003). Additionally, site characteristics have also been shown to affect plant phenolic concentrations (Covelo \& Gallardo 2001). In the study reported here, the largest amounts of tannins were obtained when plants were inoculated and fertilized only with $\mathrm{P}+\mathrm{K}$. This indicated that not only inorganic $\mathrm{N}$ status in soil but also inoculation of $A$. angustissima with $S$. mexicanum might increase its plant tannin content.

$\mathrm{P}$ is essential for biosynthesis of nucleic acids, phospholipids, coenzymes and ATP all affecting photosynthesis, protein formation and $\mathrm{N}_{2}$ fixation (Buchanan et al. 2000). As such, plant development increases when $\mathrm{P}$ is added to plants. Additionally, $\mathrm{P}$ stimulates nodulation of legumes (Hellsten \& HussDanell 2000), but how is still largely unknown.

Inoculation of $A$. angustisisma seedlings with S. mexicanum increased plant yield as much as did the addition of $\mathrm{N}$, when seedlings were fertilized with $\mathrm{P}$ and $\mathrm{K}$. It is difficult to speculate what might have caused this, but a lack of $\mathrm{N}$ might have been the reason.

It was found that $\mathrm{N}$ reduced number of nodules, tannin content and nitrogenase activity of $A$. angustisisma. As such, farmers should refrain from applying $\mathrm{N}$ fertilizer, but could apply $\mathrm{P}$ and $\mathrm{K}$ to maximize tannin production in A. angustissima.

\section{ACKNOWLEDGMENTS}

We thank the plant biotechnology laboratory from the Technological Institute of Tuxtla Gutierrez (Chiapas, Mexico) for providing facilities for this investigation and the Centro de Ciencias Genómicas-UNAM (Cuernavaca, Morelos) for the determination of nitrogenase activity.

\section{REFERENCES}

Ashley, M.K., M. Grant \& A. Grabov. 2006. Plant responses to potassium deficiencies: a role for potassium transport proteins. Journal of Experimental Botany 57: 425-436.

Barahona, R., C.E. Lascano, R.C. Cochran, J.L. Morril \& E.C. Titgemeyer. 1997. Intake, digestion, and nitrogen utilization by sheep fed tropical legumes with contrasting tannin concentration and astringency. Journal of Animal Science 75: 1633-1640.

Booker, F.L. \& MAIER, C.A. 2001. Atmospheric carbon dioxide irrigation and fertilization effects on 
phenolic and nitrogen concentrations in loblolly pine (Pinus taeda) needles. Tree Physiology 21: 609-616.

Bremmer, J.M. 1996. Nitrogen-total. In: D.L. Sparks (ed.), Methods of Soils Analysis Part 3. Chemical Methods. Soil Science Society of America Inc., American Society of Agronomy Inc., Madison, WI, pp. 1085-1122.

Buchanan, B.B., W. Gruissem \& R.L. Jones. 2000. Biochemistry and molecular biology of plants. American Society of Plant Physiologist. USA. $849 \mathrm{pp}$.

Catell, R.B. 1966. The scree test for the number of factors. Multivariate Behavior Research. 1:24576.

Covelo, F. \& A. Gallardo. 2001. Temporal variation in total leaf phenolics concentration of Quercus robur in forested and harvested stands in northwestern Spain. Canadian Journal of Botany 79: 1262-1269.

DAVIDSON, I.A. \& M.J. RoBson. 1986. Effect of contrasting patterns of nitrate uptake, $\mathrm{N}_{2}$-fixation, nodulation and growth of white clover. Annals of Botany 57: 331-338

Dzowela, B.H. 1994. Acacia angustissima a central american tree that's goings places. Agroforestry Today 6: 13-14.

Fahraeus, G. 1957. The infection of clover root hair by nodule bacteria studied by a single glass slide technique. Journal General Microbiology 16: 374-381.

FluRY, B. \& H. Riedwyl. 1988. Multivariate Statistics: A Practical Approach. Chapman and Hall, London.

Fujikake, H., A. Yamazaki, N. Ohtake, K. Sueyoshi, S. Matsuhashi, T. Ito, C. Mizuniwa, T. Kume, S. Hashimoto, N.S. Ishioka, S. Watanabe, A. Osa, T. Sekine, H. Uchida, A. Tsuji \& T. Ohyama. 2003. Quick and reversible inhibition of soybean root nodule growth by nitrate involves a decrease in sucrose supply to nodules. Journal of Experimental Botany 54:1379-1388.

Grillasca, M.M.A. 2007. Laca Chiapaneca: Ensayo de una singular aventura. Consejo Estatal para las Culturas y las Artes de Chiapas, 127 pp. CONECULTA, México.

Hättenschwiler, S., A.E. Hagerman \& P.M. Vitousek. 2003. Polyphenols in litter from tropical montane forests across a wide range in soil fertility. Biogeochemistry 64: 129-148.

Hardy, R. 1968. The Acetylene - Ethylene Assay for $\mathrm{N}_{2}$ Fixation: Laboratory and Field Evaluation. Plant Physiology 43: 1185-1207.

Hellsten, A. \& K. Huss-Danell. 2000. Interaction effects of nitrogen and phosphorus on nodulation in red clover (Trifolium pratense L.). Acta Agriculturae Scandinavica B 50: 135-142.

Huda, S.M.S., M. Sujauddin, S. Shafinat \& M.S. Uddin. 2007. Effects of phosphorus and potassium addition on growth and nodulation of Dalbergia sissoo in the nursery. Journal of Forestry
Research 18: 279-282.

Hungria, M. \& M.A. Vargas. 2000. Environmental factors affecting $\mathrm{N}_{2}$ fixation in grain legumes in the tropics, with an emphasis on Brazil. Field Crops Research 65: 151-164.

Johnson, R.A. \& D.W. Wichern. 1998. Applied Multivariate Statistical Analysis. Prentice-Hall, N.J. Upper Saddle River, NJ.

KAISER, H.F. 1960. The application of electronic computers to factor analysis. Education and Psychological Measurements 29:141-151.

Kraus, T.E.C., R.A. Dahlgren \& R.J. Zasoski. 2003. Tannins in nutrient dynamics of forest ecosystems - a review. Plant and Soil 256: 41-66.

Kraus, T.E.C., R.J. Zasoski \& R.A. Dahlgren. 2004. Fertility and $\mathrm{pH}$ effects on polyphenol and condensed tannin concentrations in foliage and roots. Plant and Soil 262: 95-109.

Kuiters, A.T. 1990. Role of phenolic substances from decomposing forest litter in plant-soil interactions. Acta Botánica Neerlandica 27: 329-348.

Lloret, L., E. Ormeño-Orrillo, R. Rincón-Rosales, J. Martínez-Romero, M.A. Rogel-Hernández \& E. Martínez-Romero. 2007. Ensifer mexicanum sp. nov. a new species nodulating Acacia angustissima (Mill.) Kuitze in Mexico. Systematic and Applied Microbiology 30: 280290

Matthews, S., I. Mila, A. Scalbert \& M.X. Donnelly. 1997. Extractable and non-extractable proanthocyanidins in barks. Phytochemistry 45 : 405-410.

Miranda, M. 2000. Validación de 2 métodos espectrofotométricos para la cuantificación de taninos y flavonoides (quercetina) en Psidium guajaba L. Revista Cubana de Farmacia 34: 50-59.

Northup, R.R., R.A. DAhlgren \& Z. Yu. 1995. Intraspecific variation of conifer phenolic concentration on a marine terrace soil acidity gradient; a new interpretation. Plant and Soil 171: 255-262.

Northup, R.R., R.A. Dahlgren \& J.G. McColl. 1998. Polyphenols as regulators of plant-litter-soil interactions in northern California's pygmy forest: A positive feedback? Biogeochemistry 42: $189-220$

O'Donovan, L. \& J.D. Brooker. 2001. Effect of hydrolysable and condensed tannins on growth, morphology and metabolism of Streptococcus gallolyticus (S. caprinus) and Streptococcus bovis. Microbiology 147: 1025-1033.

Osier, T.L. \& R.L. LindRoth. 2001. Effects of genotype, nutrient availability, and defoliation on aspen phytochemistry and insect performance. Journal of Chemical Ecology 27: 1289-1313.

Penuelas, J. \& M. Estiarte. 1998. Can elevated $\mathrm{CO}_{2}$ affect secondary metabolism and ecosystem function? Tree 13: 20-24.

RÄSÄNEN, L.A. \& K. LindSTRÖM. 2003. Effects of biotic 
Inorganic fertilizers and rhizobial inoculation of Acaciella angustissima: RuIz-VALDIVIEzo, V.M. ET AL.

and abiotic constraints on the symbiosis between rhizobia and the tropical leguminous trees Acacia and Prosopis. Indian journal of experimental biology 41: 1142-1159.

Rhoades, C.C. \& D.C. Coleman. 1999. Nitrogen mineralization and nitrification following land conversion in montane Ecuador. Soil Biology \& Biochemistry 31: 1347-1354.

Rico-Arce, L. \& A. Rodríguez. 1998. Mimosaceae R. Br. Tribu Acacieae Benth. Flora del Valle de Tehuacán-Cuicatlán. Fasc. 20. Instituto de Biología, UNAM, Mexico.

Rico-Arce, M.L. \& S. Bachean. 2006. A taxonomic revision of Acaciella (Leguminosae, Mimosoideae). Anales del Jardín Botánico de Madrid 63: 189-244.

Rincón-Rosales, R., N.R. Culebro-Espinosa, F.A. Gutierrez-Miceli \& L. Dendooven. 2003. Scarification of seeds of Acacia angustissima (Mill.) Kuntze and its effect on germination. Seed Science and Technology 31: 301-307.

Rincón-Rosales, R. \& F.A. Gutiérrez-Miceli. 2008. Características biológicas de Acaciella angustissima (Mill.) Britton \& Rose en su habitat natural y evaluación de su potencial cortical en Chiapas, México. Agrociencia 42: 129-137.

Rincón-Rosales, R., L. Lloret, E. Ponce \& E. Martínez-Romero. 2008. Rhizobia with different symbiotic efficiencies nodulate Acaciella angustissima in Mexico including Sinorhizobium chiapanecum sp. No. that has common symbiotic genes with $S$. mexicanum.
FEMS Microbiology Ecology 67:1-15.

Sas Institute Inc. 1989. Statistic Guide for Personal Computers. Version 6.04, Ed. SAS Institute Inc. Cary.

Sena, M.M., R.T.S. Frighetto, P.J. Valarini, H. TOKESHI \& R.J. PopPI. 2002. Discrimination of management effects on soil parameters by using principal component analysis: a multivariate analysis case study. Soil Tillage Research 67: 171-181.

Toledo, I., L. Lloret \& E. Martínez-Romero. 2003. Sinorhizobium americanum sp. nov., a new Sinorhizobium species nodulating native Acacia spp. in Mexico. System Applied Microbiology 26: 54-64.

Turk, D., H.H. Keyser \& P.W. Singleton. 1993. Response of tree legumes to rhizobial inoculation in relation to the population density of indigenous rhizobia. Soil Biology \& Biochemistry 25: 75-81.

Van Breemen, N. \& A.C. FinZI. 1998. Plant-soil interactions: ecological aspects and evolutionary implications. Biogeochemistry 42: 1-19.

Vincent, J.H. 1970. A Manual for Practical Study of Root Nodule Bacteria. IBM. Handbook No. 15. Blackwell Scientific Publications, Oxford.

Williams, M.L. \& C.M. MacVean. 1995. Ethnococcidology: use of the giant margarodid, Llaveia spp. (Homoptera: Coccoidea: Margarodidae), by indigenous peoples of Mesoamerica in their culture, medicine and arts. Israel Journal Entomology 29: 147-148.

Recibido: 23.01 .09

Aceptado: 01.06.09 